NBER WORKING PAPER SERIES

\title{
THE INTEGRATION OF CHILD TAX CREDITS AND WELFARE: EVIDENCE FROM THE NATIONAL CHILD BENEFIT PROGRAM
}

\author{
Kevin Milligan \\ Mark Stabile \\ Working Paper 10968 \\ http://www.nber.org/papers/w10968
NATIONAL BUREAU OF ECONOMIC RESEARCH
1050 Massachusetts Avenue
Cambridge, MA 02138
December 2004

We thank David Green, Mike Veall, and seminar participants at the Department of Finance and the CPEG conference for helpful comments. Milligan thanks the NBER for hosting him while the paper was being written and gratefully acknowledges the support of a SSHRC Standard Research Grant. Stabile gratefully acknowledges support from the Canadian Institutes for Health Research. The views expressed herein are those of the author(s) and do not necessarily reflect the views of the National Bureau of Economic Research.

(C) 2004 by Kevin Milligan and Mark Stabile. All rights reserved. Short sections of text, not to exceed two paragraphs, may be quoted without explicit permission provided that full credit, including $\odot$ notice, is given to the source. 
The Integration of Child Tax Credits and Welfare: Evidence from the National Child Benefit Program

Kevin Milligan and Mark Stabile

NBER Working Paper No. 10968

December 2004

JEL No. H24, I38

\section{ABSTRACT}

In 1998, the Canadian government introduced a new child tax credit. The innovation in the program was its integration with social assistance (welfare). Some provinces agreed to subtract the new federally-paid benefits from provincially-paid social assistance, partially lowering the welfare wall. Three provinces did not integrate benefits, providing a quasi-experimental framework for estimation. We find large changes in social assistance take-up and employment in provinces that provided the labour market incentives to do so. In our sample, the integration of benefits can account for around one third of the total decline in social assistance receipt between 1997 and 2000.

Kevin Milligan

Department of Economics

University of British Columbia

\#997-1873 East Mall

Vancouver, BC

V6T 1 Z1 Canada

and NBER

kevin.milligan@ubc.ca

Mark Stabile

Department of Economics

University of Toronto

150 St. George Street

Toronto, ON

M5S 3G7 Canada

and NBER

mark.stabile@utoronto.ca 


\section{Introduction}

Policies such as the Earned Income Tax Credit (EITC) and the Medicaid Health Insurance Program in the US have targeted low-income families with children as priority recipients of government assistance. In Canada, the Canada Child Tax Benefit and the National Child Benefit (NCB) have similarly been designed to provide assistance primarily for families with children. Along with the goal of providing assistance to these families, both the EITC and the NCB have also been designed to encourage families to participate in the labour force, with the long-term objective of helping these families provide for themselves.

Given the explicit objective of the EITC to help promote labour force participation, much of the economics literature on the EITC has examined its labour market effects. Because the EITC is a federal program, these studies have tended to rely on variation in the program over time (Eissa and Liebman, 1996, Meyer and Rosenbaum, 2001), or on variation within the program across families (Eissa and Hoynes, 1998, Dickert, Houser and Scholz, 1995). Hotz and Scholz (2003) summarize the findings from these and other studies and draw the following broad conclusions: the EITC positively affects labour force participation of single-parent households and these effects are substantial. The EITC has a modest negative effect on labour force participation for secondary workers in two-parent families. Finally the EITC has a negative effect on hours worked for those already in the labour force, although the negative hours effect, in the aggregate, is smaller than the participation effect.

Research on European working tax credits is more limited. In the United Kingdom, Bingley and Walker (1997) find that the Family Credit increased part-time work, while Blundell et al. (2000) simulate the effects of the Working Family Tax Credit, 
uncovering positive work effects for single mothers but negative effects for married women. Several other European countries have, or have plans, to introduce similar measures. Immervoll et al. (2004) describe the pan-European landscape and simulate the effects of in-work versus universal benefits, concluding that universal benefits are only preferred if the government has a very large taste for redistribution.

We examine the labour market effects of the National Child Benefit program in Canada. The unique feature of the NCB relative to policies in other countries is its integration with social assistance (welfare) payments. Provinces agreed to subtract the federally-paid National Child Benefit Supplement benefits from provincially-paid social assistance payments. This structure allowed former welfare recipients to carry part of their social assistance payments with them into the work force, effectively lowering the welfare wall. Because certain provinces chose to not deduct the new federal benefit from recipients' social assistance cheques, we have a large and transparent source of identifying variation on which to base our estimates. In addition to the integration of benefits, several provinces also introduced small earned income supplements as part of the National Child Benefit program. Using this variation, we are able to compare the relative efficacy of these two methods of improving labour market incentives.

We calculate the federal and provincial benefits available to each family in our survey using a detailed tax and benefit simulator for the Canadian tax system. This allows us to directly estimate the marginal effects of changes in the NCB on labour force participation, social assistance receipt, hours worked, total earnings, and social assistance dollars. The continuity of the measures available offers an improvement over an approach that simply compares outcomes across discrete test and control groups. 
Our findings suggest that there were strong labour market effects from the integration of child benefits with welfare for single mothers. An additional $\$ 1,000$ in benefits deducted from social assistance payments is associated with a six percentage point decrease in social assistance take-up, and a 3.9 percentage point increase in having worked. Evidence for earnings and weeks of work on the intensive margin is much weaker, with no strong evidence of a response. Both of these findings are consistent with theory and the previous literature. Further, we find little effect of the provincial earned income benefit programs on work incentives. We speculate that this may be related to the relative visibility of social assistance integration versus the earned income benefits.

The rest of the paper proceeds as follows: Section 2 explains the National Child Benefit Program in detail. Section 3 presents our empirical strategy; section 4 describes the data sets and tax information used in our analyses. Sections 5 and 6 present our results, and section 7 concludes.

\section{The National Child Benefit Program}

The National Child Benefit (NCB) program was introduced in July, 1998 as a component of the Canada Child Tax Benefit. The NCB encompasses two programs, a federally-provided refundable tax-credit (called the National Child Benefit Supplement NCB Supplement) and provincially-provided initiatives. The stated goals of the program were to reduce child poverty, promote attachment to the labour force, and reduce overlap between federal and provincial initiatives (Department of Finance 1997).

The benefit level for each family is determined by family income and the number of children. Benefits are paid quarterly starting in July. The family income used to 
determine benefits comes from amounts reported on the tax filing of the previous calendar year, so the benefits starting in July of 1999 used income from the 1998 calendar year. Families must apply to receive benefits; applications are typically included with birth registration and other government documents at the hospital when the child is born.

The annual benefit amount in 1998 was $\$ 605$ for the first child, $\$ 405$ for the second, and \$330 for the third and additional children. The benefits are reduced with family income, starting at a threshold of $\$ 20,921$ (for 1998). ${ }^{1}$ The clawback rates were set such that the benefit would be reduced to zero when income reached $\$ 25,921$ for all family sizes. ${ }^{2}$ Figure 1 traces out the benefits as a function of family income. Importantly for our empirical strategy, the incentive to work (so long as income is less than $\$ 25,921$ ) differs sharply by the number of children. In 2002-03, the federal government spent $\$ 7.8$ billion on the Canada Child Tax Benefit. This amount represented a real increase of 32 percent over the amount spent in 1997-1998. ${ }^{3}$ Most of this increase was a result of the introduction and subsequent expansions of the NCB Supplement.

At a province's discretion, the NCB Supplement benefits could be integrated with provincial social assistance programs by deducting the NCB Supplement from social assistance payments dollar for dollar. The provinces, in return, were to use the funds saved from the social assistance payments to provide spending programs to assist low income families and for provincial income supplements. Three provinces

\footnotetext{
${ }^{1}$ We refer to the reduction of the benefit with increasing family income as a clawback. Somewhat confusingly, the reduction of social assistance resulting from the integration of benefits under the NCB is also often referred to as a 'clawback' in Canadian policy discussions. To maintain clarity, we use 'clawback' only to refer to the reduction of benefits with family income. When referring to the reduction of social assistance, we refer to 'integration' and the 'crowding out' of social assistance benefits.

${ }^{2}$ The clawback rates in 1998 were $12.1 \%$ for one child, $20.2 \%$ for two children, and $26.8 \%$ for three children.

${ }^{3}$ Dollar amounts taken from the Public Accounts of Canada (Receiver General of Canada 2003).
} 
(Newfoundland, New Brunswick, and Quebec) chose to not implement the integration of social assistance benefits, meaning that the incentive to work (described in detail below) did not exist in these provinces. ${ }^{4}$ Moreover, British Columbia's integrated Family Bonus program was introduced in 1996 and had a similar structure. We use all of this acrossprovince through-time variation in our estimation of the effect of integration.

The Quebec and British Columbia cases require more clarification. The Quebec government reduces the level of Quebec Family Allowance for each dollar of federal benefits. In British Columbia, the Family Bonus has also been adjusted by the provincial government each time the federal NCB Supplement has changed. These adjustments mean that increases in the federal benefit leave the family no better off, but re-allocate the cost of the total benefit between levels of government. These changes in who pays the benefits, however, are not relevant for our study of the integration of the NCB supplement with social assistance. We are concerned with the incentive to leave social assistance. For our purposes, it matters not whether the benefits come from the federal or the provincial government, but only whether the family's social assistance payment is reduced to account for the NCB supplement. In British Columbia, the reduction is made while in Quebec it is not. For this reason, we classify Quebec as a no-integration province and British Columbia as an integration province.

The integration of social assistance benefits under the NCB produces a strong incentive to join the labour market. ${ }^{5}$ Figure 2 presents a static labour supply model with a stylized social assistance benefit. With no work, an individual receives social assistance in the amount of AB. Between B and C, extra work results in a dollar-for-dollar decrease

\footnotetext{
${ }^{4}$ Since 2001, Manitoba has stopped integrating NCB and social assistance for families that have children under age 7. Our data only cover until 2000, so we ignore this in our analysis.

${ }^{5}$ Hotz and Scholz (2003) provide a thorough treatment of the static labour supply incentives in the EITC.
} 
in the social assistance benefit - the 100 percent marginal tax rate often called the welfare wall. At C, the social assistance benefit is exhausted and earnings lead to increased consumption until point $\mathrm{D}$. The standard result is represented by points $\mathrm{X}_{0}$ and $\mathrm{B}$. In the absence of social assistance, someone with the preferences embodied in the utility curves in the figure would prefer to be at point $\mathrm{X}_{0}$. With social assistance, point $\mathrm{B}$ is preferred, however, and the individual chooses no work.

The line segments EFG represent the change in incentives introduced by the integration of social assistance benefits under the NCB program. Because the 100 percent tax rate now ends earlier at point E, the individual keeps more of his or her earnings for work between points E and G. This may lead the individual to prefer a point such as $\mathrm{X}_{1}$ instead of point $\mathrm{B}$, meaning that the individual would join the labour force.

Figure 2 also makes the ambiguous predictions of the model for those who were already in the labour market when the benefit was introduced. For some of them, the parallel shift of the budget constraint out to EF delivers a work-reducing income effect. For those on the FG segment, both the income and the substitution effects lead to less work. Finally, for those operating to the left of point G, there is no change in incentives as the benefit is zero because of their high income.

Provincially-provided initiatives comprise the second part of the National Child Benefit program. The initiatives included both non-cash spending programs and provincial tax credit programs. The non-cash spending programs provided funding for such projects as child-care subsidies and health promotion programs, while the tax credits took the form of straight transfers or earned income credits. The provincial credits also affect and provide variation in incentives to work. For example, Ontario provides a Child Care Supplement for Working Families. In 2000, families must have at least $\$ 5,000$ of 
earnings to qualify, and the yearly benefits were $\$ 1,100+\$ 210$ (per child under the age of seven) if the family is a single parent family. Benefits are then clawed back starting at $\$ 20,000$ of family income. The details of the provincial child credits for all provinces are provided in an Appendix.

While much of our analysis focuses on the NCB Supplement, we do incorporate the provincial programs into our analysis as they also provide work incentives to mothers. Our analysis therefore allows us to compare the NCB Supplement integration with social assistance to the more EITC-like provincial programs. As these programs differ in both size and method of delivery, contrasting the two may provide some insight into the relative efficacy of each program structure.

In addition to the earned income benefits, several provinces and the federal government provide a basic level of child benefits that are not tied to employment earnings. These benefits are expected to diminish the incentive to work by extending the distance between A and B in Figure 2. With more income at zero hours of work, less work will be observed. We incorporate these 'automatic' benefits into our analysis and account for their impact in developing our empirical strategy below.

In total, the NCB program provides clear incentives to join the work force for families currently on social assistance by partially replacing social assistance with a benefit that, on net, is only received if working. In addition, the provincially-run earned income supplements provide more incentive to join the labour force. However, in both cases, the prediction for work on the intensive margin is unclear - those already working may face higher marginal tax rates on their labour so they may choose to work less. 


\section{Empirical Strategy}

Our empirical strategy aims for transparent identification of the effects of the NCB Supplement on female labour supply decisions. An alternative strategy might incorporate the kinks and twists in the budget constraint generated by child benefit policies into a structural model of behaviour. While there are advantages to either approach, we believe that our method is fruitful for answering a relatively direct policy question about a small change in benefit incentives within the existing system.

To test if child benefits have affected labour supply decisions, we run regressions of the type

$$
Y_{\text {pyki }}=\beta_{0}+\beta_{1} \text { Benefit }_{\text {pyki }}+\beta_{2} X_{\text {pyki }}+\beta_{3} \text { prov }_{p}+\beta_{4} \text { year }_{y}+\beta_{5} \text { kids }_{k}+e_{\text {pyki }} \text {, }
$$

where $p$ indexes provinces, $y$ indexes years, $k$ indexes number of children, and $i$ indexes families. We observe labour supply outcomes $Y_{p y k i}$ for each family and regress them on that family's observed benefits Benefit ${ }_{p y k i}$, a set of province dummies $\operatorname{prov}_{p}$, a set of year dummies year $r_{y}$, a set of dummies for the number of children $k i d s_{k}$, and a vector of other relevant controls $X_{p y k i}$, leaving a residual term $e_{p y k i}$.

The vector $X_{p y k i}$ contains demographic controls about the family as well as $2^{\text {nd }}$ order interaction terms between the province, year, and children dummies. In this standard triple-difference specification, identification of the policy effect comes from variation within province-year cells; between families of different sizes. In other words, the policy effect is measured by comparing, for example, women in Ontario in 1997 with no kids to those with other numbers of children in the same province in the same year. This strategy is therefore robust to any shock that may differentially affect provincial labour markets and is correlated with the policy variable. 
Specifically, provincial spending programs under the NCB typically do not discriminate based on the number of children in the family. Since our strategy compares women with different numbers of children within provinces, the NCB non-cash spending programs shouldn't affect our estimates. Similarly, if there are other labour market policies we do not consider in our empirical model that vary at the province-year level, our estimates will not be affected so long as the excluded policy affects everyone in a given province in a given year in the same way.

A key assumption underlying this approach is the exogeneity of the province of residence, year, and number of children. For the province, this assumption would be violated if individuals switched provinces in order to benefit from different incentive structures. We consider this possibility unlikely, as the benefits are unlikely to surpass the costs of moving. The number of children may also be influenced by benefits. Assuming that children are exogenous to benefits is standard in the EITC literature in the US (see Hotz and Scholz 2003), but the assumption may be violated if fertility decisions depend on fiscal incentives. Milligan (2002) found strong evidence that fertility did respond to fiscal incentives in Quebec's Allowance for Newborn Children program in the late 80s and early 90s, but found much less evidence of a response among women more likely to be at-risk for being on welfare.

We pursue two strategies to overcome this challenge. First, we present our results using only the province-year variation in the benefits, finding results consistent with those that also incorporate the variation induced by the number of children. Second, we also present results excluding children under age 6. Since the NCB program was introduced in 1998 and our data run only until 2000, the decision to have the older 
children clearly preceded the introduction of the program and therefore could not have been influenced by its incentives.

\section{Endogeneity of benefits}

The observed benefit depends on the province, year, number of children, and income of the family. Importantly, family income is determined by many of the outcomes we intend to study as regressands, such as earnings, hours, and weeks worked. This introduces a mechanical endogeneity between observed benefits and the measures of labour supply.

To overcome the endogeneity problem, we implement an instrumental variables strategy similar to one pioneered by Currie and Gruber (1996). The essence of the strategy is to form an instrument that simulates benefits using only the exogenous determinants of benefits. As no particular family's income influences the simulated benefit, the mechanical endogeneity is purged.

In our case, we assume that the province of residence, year, and number of children are exogenous components. To form our instrument, we take a sample of families and calculate the benefits for each province-year-number of children combination. The simulation sample is a 10 percent random sample of the families in our five years of SLID data. As we have 5 years of data, 10 provinces, and 4 family sizes (0 to 3 children), this means that we must perform 200 benefit simulations for each family in the simulation sample. Importantly, the same set of families is put through the benefit calculator for each province-year-children combination, meaning that the benefits calculated in each cell do not embody differences in income or other characteristics across cells. The mean benefit over the simulation sample of families in each cell is then 
matched back to the original dataset by province, year and number of children to be used as the instrument. It can be expected to predict well each family's benefit, but will not depend on a particular family's observed labour market outcomes. The process is repeated over province-year cells to form our province-year simulated instrument.

Some of our dependent variables are binary, so our estimation uses a linear probability model. Blundell and Powell (2004) compare a semi-parametric control function approach to linear probability and probit results, finding the parametric models estimate a slope that is too steep. Their method requires a parsimonious set of covariates in order to be tractable, so it is not appropriate for our policy framework which requires a large set of controls to isolate the policy effect. However, their findings may suggest some caution in the interpretation of our results.

\section{Data}

We use the Census Family and Person files of the Survey of Labour and Income Dynamics (SLID) for the years 1996 to 2000 . The SLID is conducted annually by Statistics Canada with a stratified random sampling of Canadians. With survey weights, the data are potentially nationally representative. There is evidence, however, that the SLID has under-sampling of low income families. ${ }^{6}$ While this does not imperil our empirical strategy, it might limit the degree to which our results are nationally representative. The SLID provides detailed information on demographics, income and labour market activity at the individual level, as well as information on the family size and structure at the family level. The sample size per year is around 35 thousand census

\footnotetext{
${ }^{6}$ Frenette, Green, and Picot (2004) show that low income families are under-represented in the SLID relative to administrative tax data and to Census data. While the weights correct for under-sampling by age, province, and sex, the weights are not adjusted for under-coverage by income group.
} 
families made up of 60 thousand individuals aged 15 and higher. We select our sample based on the person files, merging in family characteristics from the family files. The focus of our analysis is mothers with children, so we keep females age 18 to $50 .^{7}$ Single women face a different employment decision than married women, so we exclude married women from our analysis. ${ }^{8}$

The benefit calculations are made using the observed income information on each woman, along with information on the province of residence, year, and number of children. Using a tax simulator, we calculate the child benefits owing to each woman under federal and provincial refundable tax credit programs. We use the output of the simulator to form our main policy variable to measure the incentive to work, which we call INTEBENS. This variable reflects the amount of child benefits that is integrated with social assistance; that crowd out social assistance payments. The reaction of labour market decisions to this variable describes what would happen if a province were to make more (or less) benefits be subtracted from provincial social assistance.

We form INTEBENS by first calculating the NCB Supplement payment owed to the family. For the provinces that reduce social assistance by the amount of the NCB Supplement payments, INTEBENS equals the amount of NCB Supplement payment in the year. For provinces that do not reduce SA payments, INTEBENS takes the value zero. For 1996 and 1997, there was no NCB Supplement benefit so the value of INTEBENS is zero in all provinces, with one exception explained below. For 1998, the NCB Supplement began in July so we impute half the NCB Supplement value for that year to

\footnotetext{
${ }^{7}$ Those under 18 are typically not eligible for social assistance. Those over 50 have few children.

${ }^{8}$ Married women are much less likely to be on social assistance. In our sample, 4.2 per cent of married women have some social assistance income compared to 16.5 per cent of single women. Among women with children, 43.5 percent of single women are on social assistance while only 4.4 percent of married women are. Moreover, the husband's income pushes most married women over the income threshold (\$25,921 in 1998) at which all NCB Supplement benefits are gone. In our simulated benefits, 74.7 percent of single mothers receive some NCB Supplement while only 17.8 percent of married mothers do.
} 
the INTEBENS variable. Finally, in British Columbia, the BC Family Bonus was clawed back from social assistance cheques starting in July 1996, so INTEBENS incorporates both the BC Family Bonus and the NCB Supplement for British Columbia.

We form the instruments described earlier in the paper using the same tax simulator. After putting our sample of families through the simulator, we select those who had positive employment earnings and take the average value of the benefit variables by province-year and by province-year-child cells. For the province-year cells, we exclude families without children from the simulation sample. For the province-yearchildren cells, we assign each family in the simulation 0 through 3 children in turn, so that we can get a benefit measure for the same set of families for all family sizes. The resulting benefits represent an exogenous measure of what benefits a working family could expect to receive given its province, year, and family size.

The outcomes we study in our analysis include four binary variables of labour market behaviour and five continuous measures of the intensity of work. We have a binary variable for any receipt of social assistance and one for having any earnings. These dummies are relatively blunt tools, as even a small amount of income will turn the outcome variable to a one. A more subtle measure is also provided in the SLID that indicates the 'major' source of income for the family. ${ }^{9}$ We form a dummy for having government transfers as the major source of income, and a dummy for earnings as the major source of income. The continuous measures include earnings, social assistance income, total income, hours worked, and weeks worked. All of these are measured over the calendar year in question.

\footnotetext{
${ }^{9}$ The major source of income variable is defined by the SLID. Across several income categories (earned income, pensions, government transfers, etc.), the major source is defined as the category with the highest level of income.
} 
Table 1 shows our labour market dependent variables across different family sizes. Except for earnings, all measures of labour supply decrease monotonically with the number of children, while the measures of social assistance increase monotonically with the number of children. Single women with children are large recipients of social assistance. More than half of single women with three or more children show some social assistance income, and 55.7 percent of them have transfers as the major source of income. Still, more than 63 percent of them have some earnings in the year.

Descriptive statistics for our independent variables are provided in Table 2. The first column presents the means and standard deviations of many of our variables for the full sample of single women. The next three columns present the same statistics for subsamples of interest - mothers of children, major transfer recipients and those who are not major transfer recipients. The 34,018 women in the full sample receive, on average over all years, $\$ 87.65$ of integrated NCB benefits (INTEBENS). Looking just at mothers of children, the benefits are higher at $\$ 419.39$. The mean over observations with positive of INTEBENS is $\$ 1,179.99$. For major transfer recipients, INTEBENS is larger on average than for those who are not major transfer recipients.

Over 16 percent of women have positive social assistance income, rising to over 43 percent of single women with children. Correspondingly, positive earnings is higher for the full sample of women than for the subsample of mothers, at 0.817 compared to 0.703 . Looking in the last two columns, it is clear that those who have transfers as their major source of income work much less than those who do not. The education levels of the different samples vary significantly. Transfer recipients are much more likely to be high school dropouts, at 31.3 percent versus 11.1 percent for those who are not major transfer recipients. Finally, major transfer recipients are more likely to have children, and those 
children are more likely to be young, than single women who are not major transfer recipients.

Table 3 provides further detail on our policy variables. We show the mean of four different policy variables for single mothers for each year and province in our sample. The upper left section of the table shows the values for INTEBENS. Newfoundland, New Brunswick, and Quebec show zero in all years because these provinces do not reduce social assistance payments for child benefits received. The British Columbia row shows the introduction of the BC Family Bonus half way through 1996 and for the full year in 1997. The provinces that integrated have the NCB Supplement introduced in July, 1998, and fully in place for 1999 and 2000. The observed differences among provinces that are integrated reflect differences in characteristics such as income and number of children. Our IV strategy will discard these differences and focus on the policy variation. The discussion of the other policy variables in Table 3 is deferred until Section 6 when the results for those variables are discussed.

\section{Main Results}

To begin our analysis of results, we present graphs of some of our labour market outcome variables through time. We then report results for OLS regression that do not account for the mechanical endogeneity of benefits with work in order to motivate the need for our instrumental variables strategy. Next, we present results for INTEBENS using our IV strategy based on province-year cells, followed by a similar strategy that allows for variation in the number of children. Finally, we show the sensitivity of our results to several alternative sample selection criteria. 


\section{Graphs of dependent variables through time}

Figures 3 through 6 graph our binary outcomes variables for provinces who integrated social assistance and child benefits and for those who did not. Because British Columbia effectively reduced social assistance for the entire period, it is omitted from these graphs to maintain clarity. Figure 3 shows the proportion of women having positive social assistance income. Before 1998, when there was no NCB Supplement, social assistance receipt was trending downward in both sets of provinces, possibly reflecting improving national labour market conditions. After 1998, social assistance receipt in those provinces that reduced social assistance (referred to as integration provinces) drops below that seen in the no-integration provinces, consistent with people moving from welfare to work following the NCB Supplement incentives.

Figure 4 repeats the analysis for the variable indicating positive earnings. There is little difference to be seen between the two lines over time as both increase by more than 15 percentage points over this time period. In Figures 5 and 6, however, the results are much clearer. Figure 5 has the graph for having government transfers as the major source of income. There is a clear drop in the integration provinces from 45.5 percent in 1998 to 31.7 percent in 2000. The line for the no-integration provinces, however, is flat. An equal and opposite reaction is seen for the variable indicating earnings as the major source of income. From 1998 to 2000, there was an increase of over 12 percentage points in the crowd-out provinces and only 2 percentage points in the no-integration provinces.

The graphical analysis has provided some preliminary visual indication that a sharp change in employment and social assistance receipt may have occurred after 1998 in the integration provinces, but not in the no-integration provinces. The regression analysis in 
the rest of this section aims to uncover stronger more convincing evidence of what can be seen in the figures.

\section{$\underline{\text { OLS Results }}$}

Our main regression results are reported in Table 4. We report the coefficient on INTEBENS, scaled in $\$ 1,000$ s of 2000 Canadian dollars. This means that the estimated coefficient represents the predicted change in the outcome variable when $\$ 1,000$ more child benefits becomes subject to the social assistance crowd out through the integration of benefits and social assistance. All reported standard errors are corrected by clustering on the level of aggregation of the benefit variable, which in some cases is province-year cells and for others is province-year-children cells.

The first column reports OLS regression results of the outcome variables on INTEBENS and the set of control variables for the sample of single mothers. For each regression, we only report the coefficient on the benefit variable. Since benefit levels first rise with earnings and then later fall for those with higher family income, the predicted sign for the estimated coefficients is unclear - those with zero benefits could be women who did not work at all or they could be women who earned very much and saw their benefits completely clawed back. Correspondingly, the estimated coefficients are hard to interpret. The estimated coefficient on social assistance receipt is 0.136 , suggesting a 13.6 percentage point increase in receipt when benefits increase by $\$ 1,000$. Having positive earnings, however, is predicted to decrease by 8.1 percentage points. High earning women have their benefits completely clawed back because of their higher family income, so high earners tend to have no benefits. This mechanical endogeneity 
demonstrates the difficulties inherent in using observed in-work benefit amounts to study labour market behaviour.

\section{$\underline{\text { IV Results }}$}

To correct for this endogeneity, we turn to our first set of IV estimates in the second column. Here, we maintain our focus on women with children. As an instrument for benefits, we use the simulated province-year cell mean of INTEBENS. This measure of benefits throws away any individual variation in family size or income and picks up only across-province, across-time variation in benefit levels. The first stage is a regression of INTEBENS on the province-year cell mean of simulated benefits. The first stage is very strong, with a \$1 increase in the cell mean benefits predicted to increase individual imputed benefits by $\$ 0.916$.

The four measures of labour market participation all have the expected sign, and three are statistically significant. A $\$ 1,000$ increase in benefits leads to a 5.2 percentage point decrease in having positive social assistance income. The mean social assistance receipt in this population is 43.5 percent, so the estimate implies an 11.9 percent decrease in social assistance receipt. The variable indicating transfers as the major income source is more responsive, with an estimated coefficient of -0.092 . The binary measures of earnings have weaker results, with the indicator for positive earnings showing an insignificant coefficient. However, the variable for having earnings as the major income source is highly responsive, with a predicted increase of 7.3 percentage points. The mean of this variable in the sample of women with children is 0.502 , so the estimate represents a 14.5 percent increase over the mean. The stronger results for the 'major source' 
variables indicate that most of the response comes from women with a little labour force attachment who move to have greater labour force attachment, rather than from women with precisely zero attachment joining the labour force.

To put these estimates in context, consider a woman with one child contemplating the welfare or work decision. On welfare, assume that she would receive $\$ 850$ per month, or $\$ 10,200$ annually. If she worked at an $\$ 8$ per hour job for 40 hours per week for 52 weeks, she would earn $\$ 16,640$; an increment of $\$ 6,440$ over social assistance. A thousand dollar increase in INTEBENS would imply that the increment to income from choosing work would increase by 15.5 percent to $\$ 7,440$. For the social assistance receipt variable therefore, the implied elasticity in this example is 0.77 (11.9 percent / 15.5 percent). In the US literature on the EITC, Hotz and Scholz (2003) conclude that the range of credibly estimated elasticities is between 0.69 and 1.16. So, our first estimate lies comfortably in that range.

The continuous labour supply measures show a mixed response. The point estimate on earnings is quite high - suggesting that earnings increase by $\$ 1,010.9$ for a $\$ 1,000$ increase in integrated benefits, although the standard error is quite large. With the higher earned income, it is not surprising that total income is also predicted to be higher with more integration. Finally, we estimate an increase in hours worked of 97.7 but no significant increase in weeks worked.

For social assistance, the estimated effect of making another thousand dollars subject to integration is a decrease of $\$ 747$. This result is composed of two effects. First, some families move from social assistance to work and therefore no longer collect any social assistance. Second, for those who stay on social assistance, the dollar-for-dollar crowd-out of social assistance income also leads to a mechanical decrease in social 
assistance income when INTEBENS increases. Because not all women in the sample are on social assistance, we shouldn't expect the dollar-for-dollar crowd out to result in a coefficient of -1000.0 .

In the third column we expand the sample to include single women without children. We form the instrument for this sample by using the same province-year cells as before, but now include benefits at zero for the childless families. These women serve as a control for unobserved factors in each province-year location such as labour market conditions or other labour market policies, as the childless single women live in the same province and act in the same labour markets but do not receive any benefits. We include dummies for having no children, as well as second order interactions of having no children with province and year effects. In such a specification, the policy effect is therefore identified by differences in labour supply between childless women and women with children in any given province-year combination.

For the binary labour market indicators, the point estimates are uniformly larger when we include the childless women in column (3). Welfare receipt is now predicted to decrease by 6.5 percentage points for a $\$ 1,000$ increase in integrated benefits. The positive earnings indicator is still not statistically significant, but the point estimate is 2.3 percentage points larger than the previous specification.

The continuous measures of labour supply again show less of a response than the binary indicators. The estimated effect on earnings is now almost exactly zero. This may indicate that the previous large positive estimate was simply picking up trends in earnings across provincial labour markets or some other unobserved factor. Social assistance income is still strongly negative, with an estimated average crowd out of $\$ 825.2$ for each 
$\$ 1,000$ in integrated benefits. We still find a positive impact on hours worked, with a predicted increase of 70.4 hours per year.

Finally, in the fourth column of the table we use a more flexible instrument that allows for variation in the benefit corresponding to the number of children in the family. While this contributes more identifying variation, it could be argued that the variation is not exogenous; that the number of children might respond to the benefits incentive. We examine this possibility later in this section. The point estimates in this column are very similar to the previous specification, but more precisely measured. The coefficient on the indicator for having positive earnings is now slightly stronger and reaches the 10 percent level of statistical significance.

Using the estimated coefficient for social assistance receipt of -6.0 percentage points, we can assess the magnitude of the contribution of the NCB Supplement integration to the overall downward trend in social assistance receipt. We take 1997 as the base year as it is the last full year before the NCB was introduced. ${ }^{10}$ In provinces with crowd-out, social assistance take-up among single women declined from 48.7 percent to 35.4 percent in our sample between 1997 and 2000. The average value for INTEBENS in integration provinces was $\$ 1097.55$, compared to $\$ 290.6$ in 1997 , a difference of $\$ 806.95$. ${ }^{11}$ The coefficient of -6.0 per thousand dollars suggests that this increase in integrated benefits can account for a decline in social assistance receipt of 4.8 percentage points, which is 36.5 percent of the total decline of social assistance receipt of 13.3 percentage points in the integration provinces over the 1997-2000 period. So, our estimates suggest that the

\footnotetext{
${ }^{10}$ The calculation produces a similar result using 1996 as the base year.

${ }^{11}$ Before 1998, residents of British Columbia were eligible for the BC Family Bonus which was subtracted from social assistance. The value of INTEBENS in all other provinces was zero before 1998.
} 
integration of the NCB Supplement with provincial social assistance programs can account for about one third of the decline in social assistance receipt.

\section{Sample Sensitivity Checks}

To assess the sensitivity of our results to some of our assumptions, we present the results for alternative samples in Table 5. For the results in column (2), we identify a population that we might expect to have a larger response and see if it is so. Women with children under age six have much greater childcare demands than those of school-going age. For this reason, the responsiveness of mothers with young children may be limited. Restricting the sample to women with children at least 6 years old also helps as a robustness check against the possibility that fertility may be endogenous. Children aged six or more were born before the NCB policy was contemplated, so can be considered exogenous to the policy. Compared to the base results, the restricted sample has much larger coefficients. The coefficient on integrated benefits for the regression with positive social assistance income, for example, more than doubles to -0.130 .

In the third column, we try another restriction for a sample we think may be more responsive. Most women over age 24 will have completed their education, while a large proportion of women in their late teens are still potentially in school. By selecting a sample of women more active in the labour market, we expect to see a higher sensitivity to the incentives in the NCB. We find point estimates that are statistically indistinguishable from the base case, although they are uniformly larger. Taken together with the results in column 2, the results appear to vary sensibly in suitably chosen subsamples. 
The final column of Table 5 shows the results excluding Quebec. Because Quebec did not participate in the NCB (although Quebec residents still receive the NCB Supplement) and because Quebec's policy environment differs in many other ways, we restrict our sample in column 4 to provinces other than Quebec. The results suggest that the possibly confounding Quebec factors are not driving our results.

\section{Results including other policy variables}

Contemporaneous with the introduction of the NCB Supplement and the integration with social assistance payments, several provinces introduced new child benefit programs. In addition, there were other changes at the federal benefit level over our sample period. Finally, social assistance rates continued to evolve between 1996 and 2000. The impact of any of these policy changes on the labour market behaviour of single women is of interest on its own. However, it is of particular interest here because other policy changes may be confounding our findings for the integration of social assistance payments through the NCB program. In this section, we pursue analysis of all of the policy changes mentioned above.

The first additional policy variable we create is WORKBENS. This variable records the benefits of earned income credits for those who work. This includes the inwork benefits available in some provinces as part of the provincial component of the NCB program as well as the federal Working Income Supplement and the small Goods and Services Tax Credit. (More information on these programs is available in the Appendix.) We next compute a variable we call AUTOBENS. This variable accounts for benefits that are paid 'automatically' to families without conditioning on earnings. Included in this measure are several provincial benefits and the federal Canada Child Tax 
Credit. This measure also accounts for the net increase in benefits (if any) received in provinces that don't integrate the NCB Supplement with social assistance benefits. ${ }^{12}$ The final policy variable we form is PROVSA. This variable measures the statutory level of social assistance benefits payable to the family if it were on social assistance. We gather the data on provincial social assistance from the National Council on Welfare (2003). The available rates vary by province and by year, and as well between single families with no children and with children.

The province-year variation in these policy variables can be seen in Table 3. For WORKBENS in 1996 and 1997, the federal Working Income Supplement was in effect. The amounts vary in the table by province because of differing income levels - our instrumental variables strategy removes this income variation leaving no identifying information from the Working Income Supplement since our year dummies will account for national variation. For the last three years, residents of New Brunswick, Ontario, Saskatchewan, Alberta, and British Columbia were eligible for earned income supplements. $^{13}$ For the automatic benefits, the policy variation comes from small provincial credits under the NCB program, as well as increased automatic benefits for the provinces that did not integrate NCB payments. Finally, statutory social assistance payments changed little over this period, with the observed within-province variation reflecting differing price-indexation across provinces and differences in family composition across cells.

In Table 6, we present evidence using the alternative benefit measures to gauge the importance of other provincially-varying benefits versus the NCB Supplement. In all

\footnotetext{
12 Because British Columbia and Quebec reduce provincial child benefits when federal benefits increase, AUTOBENS does not increase when the NCB Supplement is introduced in these provinces.

${ }^{13}$ New Brunswick's earned income credit was introduced in 1997, before the NCB. Details on all programs are provided in the Appendix.
} 
cases we use the same specification as column (4) of Table 4, exploiting child, year, and provincial variation. For WORKBENS and AUTOBENS we use the same IV strategy as we used for INTEBENS to predict benefits, but for PROVSA we simply use the statutory benefit rates available to the family as the policy variable.

The results in Table 6 use each of the policy variables in isolation, and then combine them together in the fifth column. The first column uses INTEBENS and so reproduces the results from the previous table. The second column uses WORKBENS. Higher provincial in-work benefits provide an incentive to work very similar to the EITC. The estimates are much less precise than for INTEBENS, meaning that it is difficult to find significant coefficients. The signs and magnitudes are not dissimilar to those measured in Column 1, with the exception of transfer major source which is about half again as large and statistically significant.

The third column uses the AUTOBENS variable. Because more benefits not conditional on earnings decrease the incentive to work, we expect to find opposite signs than we found for the first two columns. The results do show the expected sign pattern, with both of the 'major source' variables showing strongly significant coefficients.

The effect of provincial social assistance rates is estimated to be strong and positive for having any social assistance income. However, the other three point estimates are uniformly close to zero, although imprecisely estimated. The lack of strong variation in provincial social assistance rates over this period may contribute to these inconclusive findings.

The final column puts all four policy variables in the same regression. For all four dependent variables, the point estimate and significance level for INTEBENS is stronger in column (4) than in column (1), suggesting that other provincial programs omitted from 
the regressions are not driving the results we saw in the main results. The estimates for WORKBENS and PROVSA are positive for having any social assistance income, but insignificant for the other three dependent variables.

From this evidence we draw two conclusions; one strong and one more tentative. The stronger conclusion is that our main results on the impact of the integration of NCB benefits with social assistance are not driven by these other policies. The more tentative conclusion is that integration is a more effective policy than earned income credits or lower social assistance payments in increasing work among single females. The point estimates are almost all larger for the integration policy, but the imprecision of the earned income supplement estimates renders this conclusion more speculative.

One potential explanation for the stronger effect of integration compared to earned income credits is that the NCB Supplement is directly subtracted from the recipients' monthly social assistance cheques. Recipients are therefore made well aware that they must work to receive additional benefits. On the other hand, the provincial programs are often administered separately, or through tax returns. While the incentive structure may be similar, recipients may not be as aware of potential work incentives and crowd-out effects. Previous work has documented the relationship between take-up and the visibility of the program (Currie, 2004). In our case individuals need not apply separately for the federal and provincial programs, and as such differential take-up is not driving differences here. However, the transparency of the mechanisms by which the programs promote workforce participation does differ and transparency arguments may indeed explain part of the differential effects on labour supply. However, we can not directly test this explanation. 


\section{Conclusions}

In this paper, we study the introduction of the National Child Benefit program in Canada in 1998. Because some provinces chose to integrate the benefits with their social assistance programs and some did not, cross-province variation in the incentives to leave social assistance were introduced. We exploit these differences and find a large, statistically and economically significant effect on social assistance take-up and work. The magnitudes of the effects we estimate are within the range of those found in the EITC literature in the United States. Our estimates suggest that about one third of the total decline in social assistance receipt can be accounted for by the integration of social assistance payments. We find that the federal National Child Benefit program has much stronger effects on work than do the provincial earned income credit programs that were also designed to promote labour force participation, although the latter effects were imprecisely estimated. We speculate that a possible reason for these differences in efficacy lie in the relative transparency of the relationship between the benefit and labour force participation.

Saez (2002) stresses the importance of differentiating between the extensive and the intensive elasticities when evaluating labour market incentives. His optimal tax model recommends a benefit with a smaller transfer and an earnings exemption before receiving any benefit when the extensive elasticity is large, and a benefit with larger transfers and clawbacks starting at very low incomes when the extensive elasticity is less responsive. In the context of this model, the large extensive elasticities that we estimate may provide some justification for the integration of benefits under the NCB, as the integration effectively acts as an earnings exemption, with benefits received only by those who are working. 


\section{Appendix - Details on Child Benefits}

Below we provide details on the federal and provincial child benefits we include in our tax calculator. The discussion is split between the in-work benefits and the automatic benefits. Unless otherwise stated, the description applies to the year 2000. In all cases, the family income measured used to claw back benefits is from line 236 of the federal tax form, which is net family income (total income less deductions).

\section{In-work Benefits}

In-work benefits condition on having some employment income.

Federal Goods and Services Tax Supplement: 1991

A credit of $\$ 106$ is phased in at a rate of 2 percent for income over $\$ 6,546$. Only childless single adults are eligible. It is clawed back along with the Goods and Services Tax Credit at a rate of 5 percent for income over \$26,284.

Federal Working Income Supplement: 1993

This credit paid benefits of \$500 until 1996 and \$605, \$405, and \$330 for one, two and three children in 1997. It was phased in at a rate of 8 per cent for income higher than $\$ 3,750$, and clawed back at a rate of 10 percent for family income over $\$ 20,921$. It was cancelled in 1998.

New Brunswick Working Income Supplement: 1997

For each dollar of earned income over $\$ 3,750$, a family with children receives 4 cents more Working Income Supplement up to a maximum of \$250. Family income over $\$ 20,921$ reduces the Supplement by 5 cents until it is completely clawed back.

\section{Ontario Child Care Supplement for Working Families: 1998}

Benefits increase with earned income over $\$ 5,000$ by 21 cents per dollar for one child under age 7, 42 cents for two children under 7, and 63 cents for three or more children under 7. The maximum benefit is $\$ 1,100$ for single families and $\$ 1,310$ for married families. For income greater than $\$ 20,000$, the benefit is decreased by 8 cents per dollar of family income.

\section{Saskatchewan Employment Supplement: 1998}

The benefit is zero until $\$ 1,500$ of earned income. For earnings greater than $\$ 1,500$, the benefits are increased by 25 to 45 cents per dollar, depending on the number of children. The maximum benefit is $\$ 2,100$ for the first child, plus $\$ 420$ for each additional child. The clawback threshold is $\$ 12,900$ and the clawback rate is 25 cents per dollar of earnings over the threshold. 
Alberta Family Employment Tax Credit: 1998

The benefit pays up to $\$ 500$ to families with one child and up to $\$ 1000$ for families with two children. The benefit starts when earned income reaches $\$ 6,500$ and rise by 8 cents per dollar of income over the threshold. They begin to be clawed back at $\$ 25,000$ at a rate of 4 cents per dollar.

British Columbia Earned Income Benefit: 1998

The benefit pays up to $\$ 605$ for the first child, $\$ 405$ for the second, and $\$ 330$ for the third and fourth child. The benefit is clawed in between $\$ 3,750$ and $\$ 10,000$ at the rate necessary to ensure the maximum benefit is reached at $\$ 10,000$. The benefit is clawed back for earnings over $\$ 20,921$ at $12.1 \%$ for one child, $20.2 \%$ for two children, and $26.8 \%$ for three children.

\section{Automatic Benefits}

Automatic benefits do not condition on having employment income. They are transferred to eligible families even if they have zero earned income.

\section{Federal Goods and Services Tax Credit}

The benefit pays $\$ 202$ per adult and $\$ 106$ per child. It is clawed back with family income at a rate of 5 percent in excess of $\$ 26,284$.

\section{Federal Canada Child Tax Benefit}

The benefit pays up to $\$ 1,104$ per child. It is clawed back with family income at a rate of 2.5 percent for one child and 5 percent for two or more children for family income in excess of $\$ 26,284$.

\section{Newfoundland and Labrador Child Benefit: 1999}

The benefit pays \$204 for one child, an additional \$312 for a second child, \$336 for the third child, and $\$ 360$ for a fourth or subsequent child. It is clawed back on family income in excess of $\$ 15,921$ until the income level of $\$ 20,921$ when it is exhausted.

\section{Nova Scotia Child Benefit: 1998}

The benefit pays $\$ 403$ for one child, an additional $\$ 319$ for a second child, and $\$ 286$ for a third or subsequent child. It is clawed back with family income in excess of $\$ 16,000$ until the income level of $\$ 20,921$ when it is exhausted.

New Brunswick Child Tax Benefit: 1997 
The benefit pays $\$ 250$ per child. It is clawed back at a rate of 2.5 percent for one child or 5 percent for two or more children for family incomes in excess of $\$ 20,000$.

Quebec Family Allowance: 1998

The benefit pays $\$ 625$ per child, with an extra $\$ 1,300$ for the first child of a single-parent family. It is clawed back with family income in two tiers. First, at a rate of 25 percent (35\% for singles with one child) until a minimum benefit level is reached. Following that, it is clawed back at a rate of 5 percent for incomes higher than $\$ 50,000$. Increases in federal child benefits result in corresponding decreases in the Quebec Family Allowance.

Saskatchewan Child Benefit: 1998

The benefit pays $\$ 720$ for one child, an additional $\$ 924$ for a second child, and $\$ 996$ for a third or subsequent child. It is clawed back with family income in excess of $\$ 15,921$ at rates between 15 percent and 60.6 percent, depending on the number of children.

British Columbia Family Bonus: 1996

This benefit is integrated with the National Child Benefit Supplement. Each child entitles the parent to $\$ 1,332$ per year, from which the National Child Benefit Supplement amount is subtracted. This benefit is also integrated with provincial social assistance as social assistance payments are reduced dollar for dollar with the Family Bonus. The Bonus is clawed back on family income in excess of $\$ 18,000$ at a rate of 8 percent for families with one child and 16 percent for families with two or more children. 


\section{References}

Bingley, Paul and Ian Walker (1997), “The labour supply, unemployment and participation of lone mothers in in-work transfer programmes," The Economic Journal, Vol. 107, No. 444, pp. 1375-1390.

Blundell, Richard, Alan Duncan, Julian McCrae, and Costas Meghir (2000), "The labour market impact of the Working Families’ Tax Credit,” Fiscal Studies, Vol. 21, No. 1, pp. 75-104.

Blundell, Richard W. and James L. Powell (2004), "Endogeneity in semiparametric binary response models,” Review of Economic Studies, Vol. 71, No. 3, pp. 655679.

Currie, Janet and Jonathan Gruber (1996), "Health insurance eligibility, utilization of medical care, and child health,” Quarterly Journal of Economics, Vol. 111, No. 2, pp. 431-466.

Currie, Janet (2004), “The Take Up of Social Benefits,” NBER Working Paper No. 10488.

Department of Finance (1997), "Working together towards a national child benefit system,” Budget Documents 1997. Ottawa. Available at http://www.fin.gc.ca/budget97/child/childe.html.

Dickert, Stacey, Scott Houser, and John Karl Scholz (1995), “The Earned Income Tax Credit and transfer programs: A study of labour market and program participation,” in James M. Poterba (ed.) Tax Policy and the Economy, Vol. 9. Cambridge MA: MIT Press.

Eissa, Nada and Hillary Williamson Hoynes (1998), “The Earned Income Tax Credit and the labor supply of married couples,” NBER Working Paper No. 6856.

Eissa, Nada and Jeffrey B. Liebman (1996), "Labor supply responses to the Earned Income Tax Credit,” Quarterly Journal of Economics, Vol. 112, No. 2, pp. 605637.

Frenette, Marc, David Green, and Garnett Picot (2004), "Rising income inequality amid the economic recovery of the 1990s: An exploration of three data sources," Analytical Studies Branch Research Paper No. 219, Statistics Canada. Catalogue No. 11F0019MIE.

Hotz, V. Joseph and John Karl Scholz (2003), “The Earned Income Tax Credit,” in Robert Moffitt (ed.) Means-tested Transfer Programs in the United States. Chicago: University of Chicago Press. 
Immervoll, Herwig, Henrik Kleven, Claus Thustrup Kreiner, and Emmanuel Saez (2004), "Welfare reform in European countries: A micro-simulation analysis," CEPR Discussion Paper No. 4324.

Meyer, Bruce (2002), "Labor supply at the extensive and intensive margins: The EITC, welfare, and hours worked," American Economic Review Papers and Proceedings, Vol. 92, pp. 373-379.

Meyer, Bruce and Dan T. Rosenbaum (2001), "Welfare, the Earned Income Tax Credit, and the labor supply of single mothers," Quarterly Journal of Economics, Vol. 116, No. 3, pp. 1063-1114.

Milligan, Kevin (2002), "Subsidizing the stork: New evidence on tax incentives and fertility,” NBER Working Paper No. 8845.

National Council on Welfare (2003), “Welfare Incomes 2002.” Ottawa, ON. Available at http://www.ncwcnbes.net/index.htm.

Receiver General of Canada (2003) “Public Accounts of Canada,” Vol. 1, Ottawa.

Saez, Emmanuel (2002), "Optimal income transfer programs: Intensive versus extensive labor supply responses,” Quarterly Journal of Economics, Vol. 117, No. 3, pp. 1039-1073. 
Figure 1: NCB Supplement benefit rates for 1998

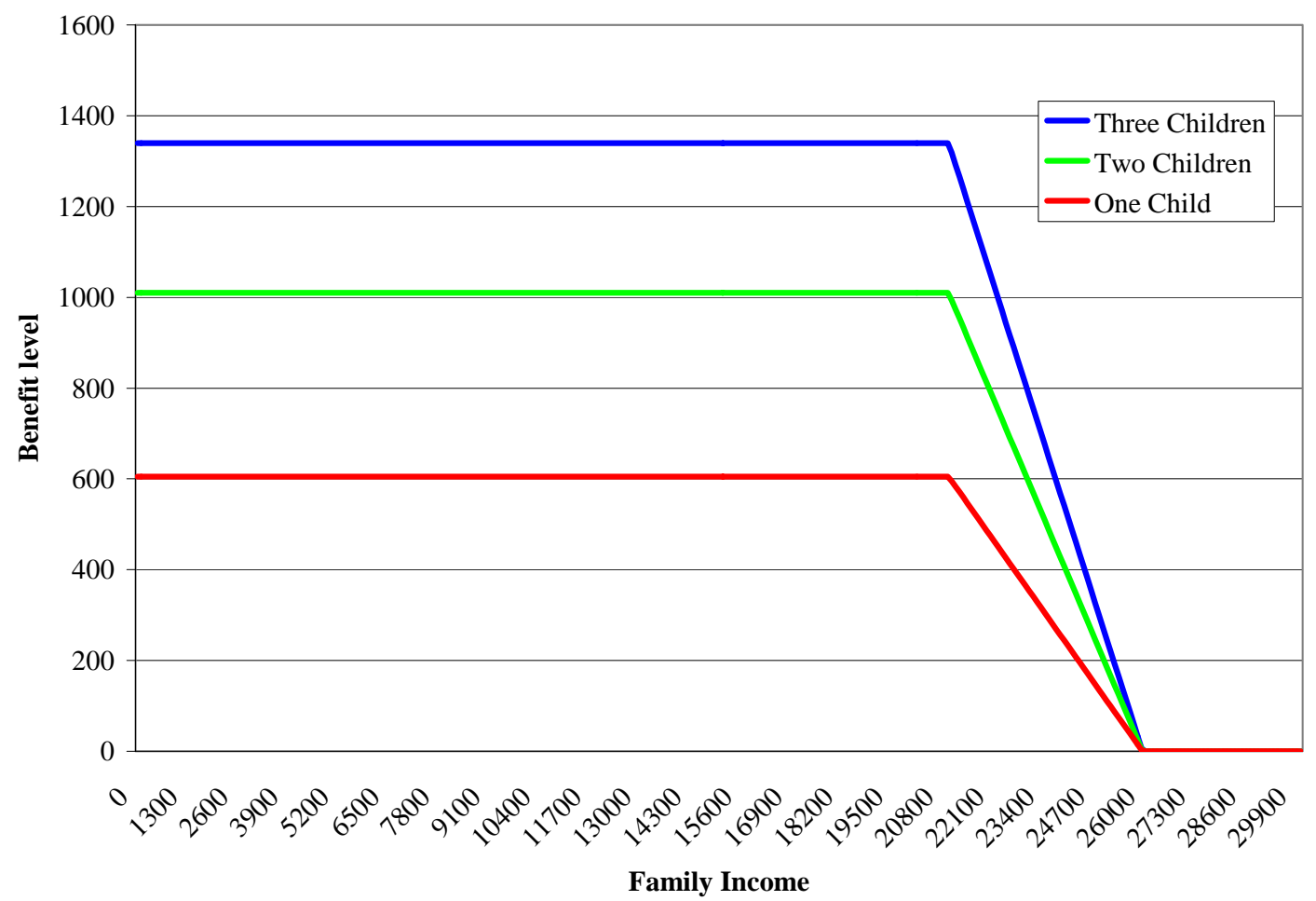

Figure 2: Static Labour Supply

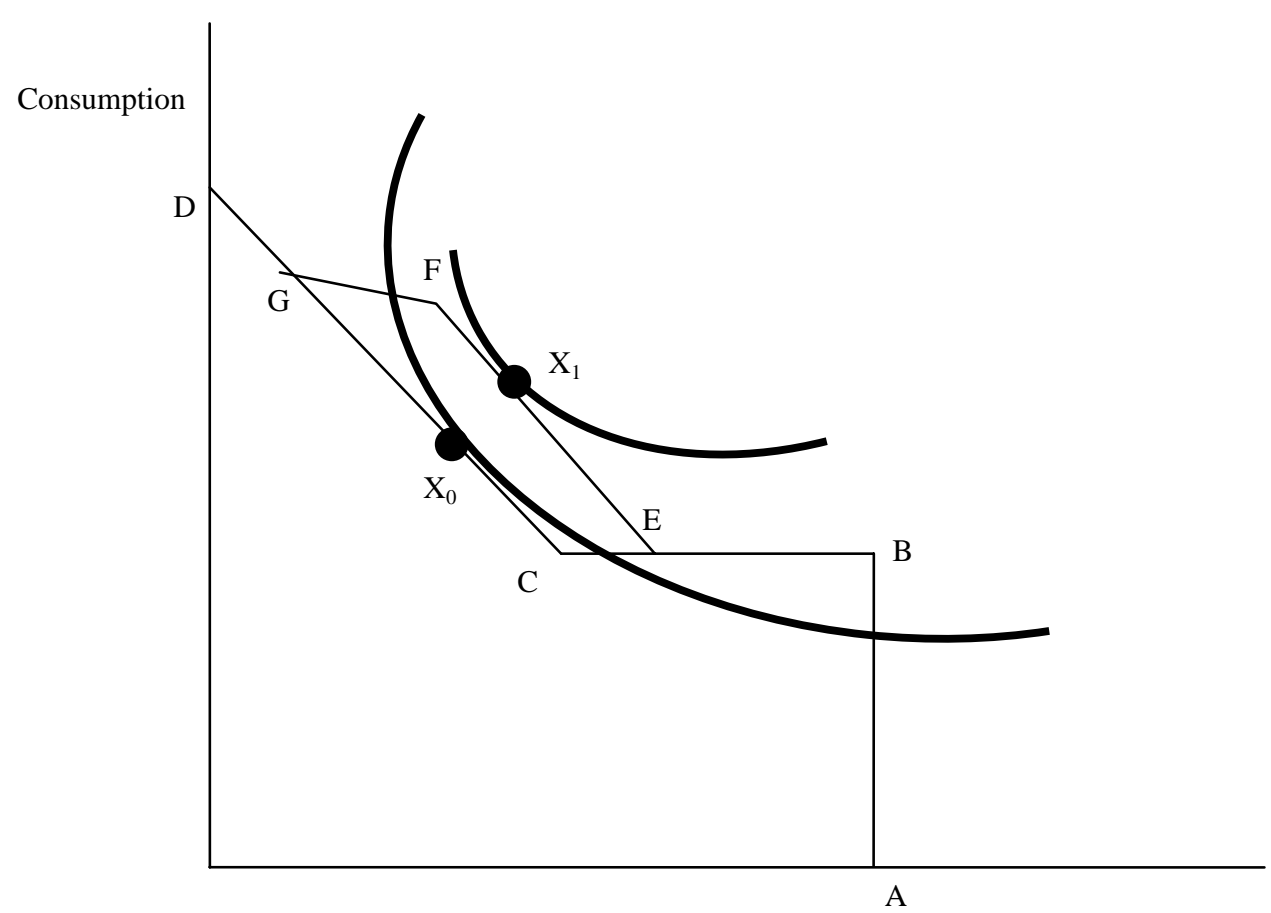

Leisure 
Figure 3: Social Assistance Receipt

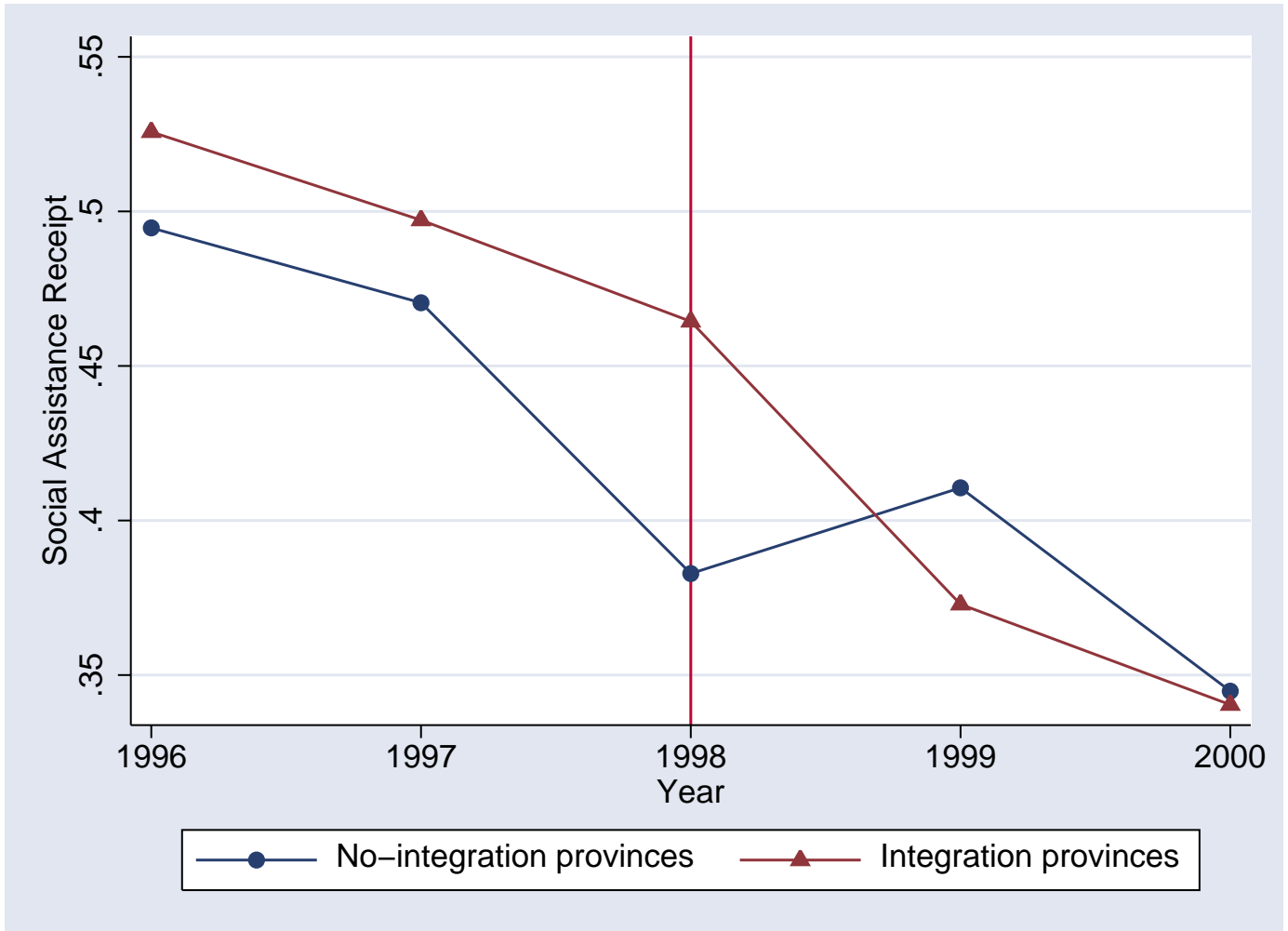

Figure 4: Positive Earnings

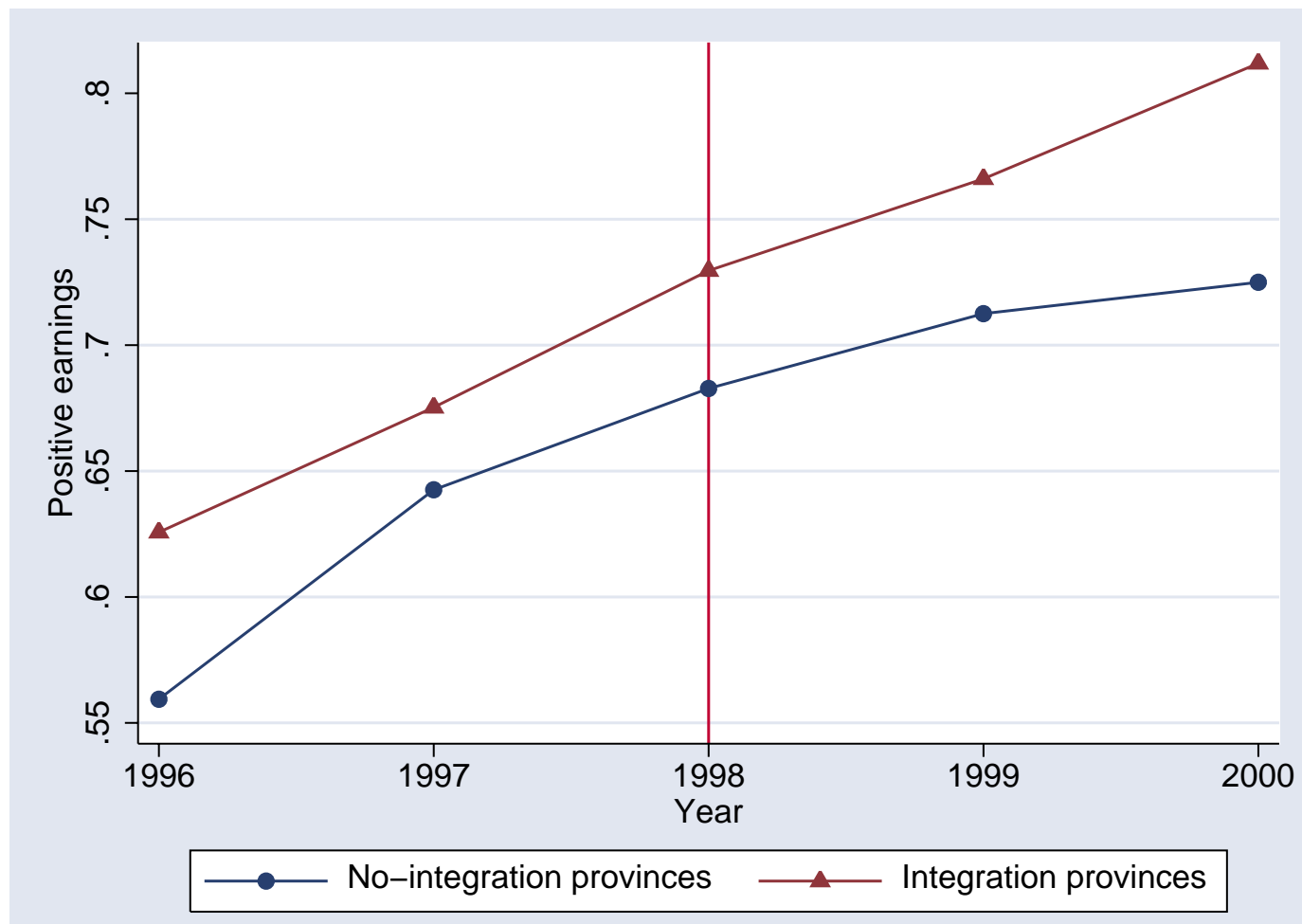


Figure 5: Transfers are Major Income Source

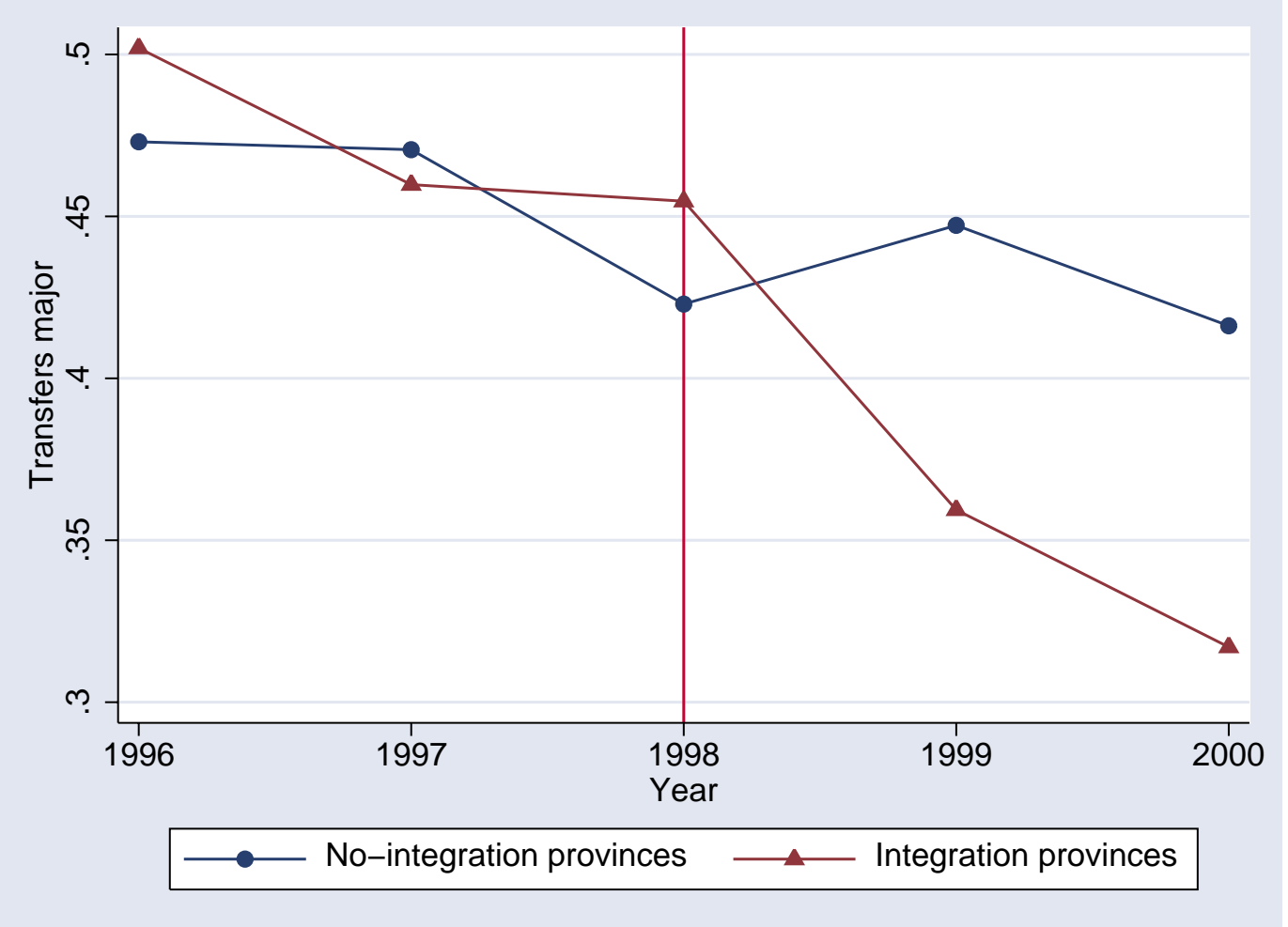

Figure 6: Earnings are Major Income Source

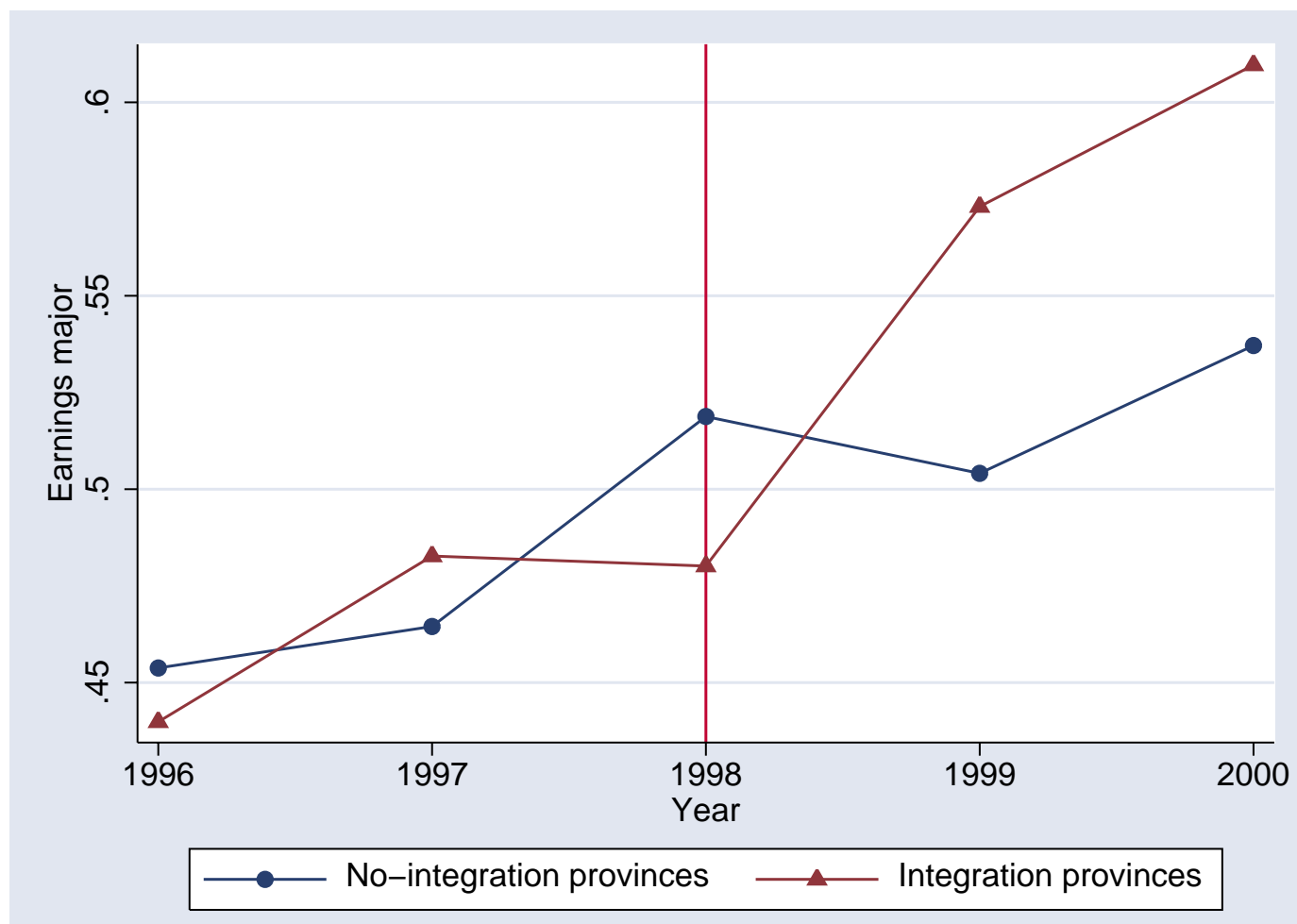




\section{Table 1: Dependent Variables By Number of Children}

\begin{tabular}{|c|c|c|c|c|c|}
\hline & $\begin{array}{c}\text { All } \\
\text { single } \\
\text { women }\end{array}$ & $\begin{array}{c}\text { Zero } \\
\text { children }\end{array}$ & $\begin{array}{l}\text { One } \\
\text { child }\end{array}$ & $\begin{array}{c}\text { Two } \\
\text { children }\end{array}$ & $\begin{array}{c}\text { Three } \\
\text { children }\end{array}$ \\
\hline observations & 34018 & 25994 & 4447 & 2682 & 895 \\
\hline Positive social assistance & 0.165 & 0.094 & 0.403 & 0.460 & 0.520 \\
\hline Transfers major source & 0.200 & 0.138 & 0.384 & 0.471 & 0.557 \\
\hline Positive earnings & 0.817 & 0.847 & 0.737 & 0.670 & 0.635 \\
\hline Earnings major source & 0.716 & 0.772 & 0.560 & 0.452 & 0.364 \\
\hline Weeks worked & $\begin{array}{c}35.8 \\
(21.9)\end{array}$ & $\begin{array}{c}36.8 \\
(21.3)\end{array}$ & $\begin{array}{c}34.1 \\
(23.4)\end{array}$ & $\begin{array}{c}30.8 \\
(24.2)\end{array}$ & $\begin{array}{c}26.3 \\
(24.4)\end{array}$ \\
\hline Hours worked & $\begin{array}{l}1139.2 \\
(900.4)\end{array}$ & $\begin{array}{l}1158.7 \\
(887.3)\end{array}$ & $\begin{array}{l}1137.1 \\
(944.7)\end{array}$ & $\begin{array}{l}1018.4 \\
(941.1)\end{array}$ & $\begin{array}{c}853.6 \\
(914.7)\end{array}$ \\
\hline Earnings & $\begin{array}{c}16396.4 \\
(18629.7)\end{array}$ & $\begin{array}{c}16546.6 \\
(18818.4)\end{array}$ & $\begin{array}{c}17088.2 \\
(18259.0)\end{array}$ & $\begin{array}{c}14775.7 \\
(17248.7)\end{array}$ & $\begin{array}{c}12803.0 \\
(17358.7)\end{array}$ \\
\hline Social assistance & $\begin{array}{c}1196.1 \\
(3173.1)\end{array}$ & $\begin{array}{c}587.9 \\
(2163.2)\end{array}$ & $\begin{array}{c}2905.0 \\
(4329.9)\end{array}$ & $\begin{array}{c}3927.9 \\
(5080.2)\end{array}$ & $\begin{array}{c}5113.2 \\
(6111.1)\end{array}$ \\
\hline Total income & $\begin{array}{c}19972.6 \\
(18290.0) \\
\end{array}$ & $\begin{array}{c}18511.8 \\
(18673.5)\end{array}$ & $\begin{array}{c}24579.0 \\
(16021.7)\end{array}$ & $\begin{array}{c}26187.1 \\
(15165.9)\end{array}$ & $\begin{array}{c}27964.4 \\
(14042.0) \\
\end{array}$ \\
\hline
\end{tabular}

Notes: All dollar values in 2000 Canadian dollars. Standard deviations are beneath continuous variables. 


\section{Table 2: Descriptive Statistics}

\begin{tabular}{|c|c|c|c|c|}
\hline & $\begin{array}{c}\text { All } \\
\text { single } \\
\text { women }\end{array}$ & $\begin{array}{c}\text { Single } \\
\text { women with } \\
\text { children }\end{array}$ & $\begin{array}{c}\text { Major } \\
\text { transfer } \\
\text { recipients } \\
\end{array}$ & $\begin{array}{c}\text { Not major } \\
\text { transfer } \\
\text { recipients }\end{array}$ \\
\hline observations & 34018 & 8024 & 7272 & 26746 \\
\hline INTEBENS & $\begin{array}{c}87.65 \\
(394.4)\end{array}$ & $\begin{array}{l}419.39 \\
(777.9)\end{array}$ & $\begin{array}{l}255.45 \\
(675.5)\end{array}$ & $\begin{array}{c}45.79 \\
(267.9)\end{array}$ \\
\hline Positive social assistance & 0.165 & 0.435 & 0.683 & 0.036 \\
\hline Positive earnings & 0.817 & 0.703 & 0.279 & 0.951 \\
\hline Age & $\begin{array}{l}30.0 \\
(9.7)\end{array}$ & $\begin{array}{l}35.6 \\
(7.6)\end{array}$ & $\begin{array}{l}32.2 \\
(9.4)\end{array}$ & $\begin{array}{l}29.5 \\
(9.7)\end{array}$ \\
\hline Education - dropout & 0.151 & 0.200 & 0.313 & 0.111 \\
\hline Education - secondary graduate & 0.134 & 0.159 & 0.148 & 0.131 \\
\hline Education - some post secondary & 0.564 & 0.552 & 0.494 & 0.582 \\
\hline Education - university graduate & 0.151 & 0.089 & 0.045 & 0.177 \\
\hline Number of children & 0.332 & 1.589 & 0.770 & 0.223 \\
\hline Child under age 6 & 0.074 & 0.352 & 0.218 & 0.037 \\
\hline
\end{tabular}

Notes: All dollar values in 2000 Canadian dollars. Standard deviations are beneath continuous variables. 
Table 3: Policy Variation By Year and Province

\begin{tabular}{|c|c|c|c|c|c|c|c|c|c|c|c|}
\hline & 1996 & 1997 & 1998 & 1999 & 2000 & & 1996 & 1997 & 1998 & 1999 & 2000 \\
\hline \multicolumn{6}{|c|}{ Average value of INTEBENS among single mothers } & \multicolumn{6}{|c|}{$\begin{array}{c}\text { Average value of WORKBENS among single mothers } \\
\end{array}$} \\
\hline Newfoundland & 0 & 0 & 0 & 0 & 0 & Newfoundland & 67 & 88 & 0 & 0 & 0 \\
\hline Prince Edward Island & 0 & 0 & 313 & 882 & 1137 & Prince Edward Island & 180 & 227 & 0 & 0 & 0 \\
\hline Nova Scotia & 0 & 0 & 397 & 992 & 1183 & Nova Scotia & 114 & 107 & 0 & 0 & 0 \\
\hline New Brunswick & 0 & 0 & 0 & 0 & 0 & New Brunswick & 97 & 198 & 74 & 63 & 86 \\
\hline Quebec & 0 & 0 & 0 & 0 & 0 & Quebec & 95 & 165 & 0 & 0 & 0 \\
\hline Ontario & 0 & 0 & 304 & 797 & 945 & Ontario & 80 & 139 & 164 & 250 & 241 \\
\hline Manitoba & 0 & 0 & 346 & 1027 & 1112 & Manitoba & 162 & 226 & 0 & 0 & 0 \\
\hline Saskatchewan & 0 & 0 & 378 & 1040 & 1226 & Saskatchewan & 175 & 269 & 788 & 802 & 703 \\
\hline Alberta & 0 & 0 & 289 & 695 & 862 & Alberta & 193 & 257 & 278 & 337 & 243 \\
\hline British Columbia & 849 & 1653 & 1540 & 1700 & 1619 & British Columbia & 124 & 151 & 238 & 297 & 240 \\
\hline \multicolumn{6}{|c|}{$\begin{array}{c}\text { Average value of } A U T O B E N S \text { among single mothers } \\
\end{array}$} & \multicolumn{6}{|c|}{$\begin{array}{c}\text { Average value of } P R O V S A \text { among single mothers } \\
\end{array}$} \\
\hline Newfoundland & 1900 & 1912 & 2560 & 2938 & 3678 & Newfoundland & 11271 & 11373 & 11449 & 11508 & 11607 \\
\hline Prince Edward Island & 1896 & 2032 & 2291 & 2072 & 2117 & Prince Edward Island & 10250 & 9984 & 9680 & 9282 & 9599 \\
\hline Nova Scotia & 2214 & 2222 & 2842 & 2508 & 2663 & Nova Scotia & 10568 & 10571 & 10394 & 10158 & 10047 \\
\hline New Brunswick & 1946 & 2170 & 2771 & 2992 & 3382 & New Brunswick & 9580 & 9851 & 9934 & 9930 & 9926 \\
\hline Quebec & 2280 & 2190 & 4177 & 4323 & 4459 & Quebec & 11537 & 11104 & 10835 & 10547 & 10295 \\
\hline Ontario & 2067 & 1962 & 2278 & 2002 & 2063 & Ontario & 11949 & 11976 & 11670 & 11277 & 11097 \\
\hline Manitoba & 1902 & 2021 & 2335 & 2433 & 2246 & Manitoba & 9644 & 9647 & 9344 & 8946 & 8975 \\
\hline Saskatchewan & 2234 & 2267 & 3351 & 3155 & 3110 & Saskatchewan & 10389 & 10393 & 9298 & 9488 & 9458 \\
\hline Alberta & 2139 & 2086 & 2281 & 1954 & 1954 & Alberta & 9198 & 9278 & 9194 & 9084 & 8972 \\
\hline British Columbia & 2975 & 2149 & 2054 & 2078 & 2210 & British Columbia & 11973 & 11928 & 11624 & 11237 & 11161 \\
\hline
\end{tabular}


Table 4: Main Regression Results

\begin{tabular}{|c|c|c|c|c|c|c|c|c|}
\hline \multirow[b]{3}{*}{ sample } & \multicolumn{2}{|l|}{ (1) } & \multicolumn{2}{|l|}{ (2) } & \multicolumn{2}{|l|}{ (3) } & \multicolumn{2}{|l|}{ (4) } \\
\hline & OLS & & IV & & IV & & IV & \\
\hline & $\begin{array}{c}\text { single } \\
\text { mothers }\end{array}$ & & $\begin{array}{c}\text { single } \\
\text { mothers }\end{array}$ & & $\begin{array}{l}\text { all single } \\
\text { women }\end{array}$ & & $\begin{array}{l}\text { all single } \\
\text { women }\end{array}$ & \\
\hline Instrument variation & -- & & Prov-year & & $\begin{array}{l}\text { Prov-year- } \\
\text { has childre }\end{array}$ & & $\begin{array}{r}\text { Prov-year- } \\
\text { number child }\end{array}$ & \\
\hline observations & 8024 & & 8024 & & 34018 & & 34018 & \\
\hline First stage & -- & & $\begin{array}{c}0.916 \\
(0.026)\end{array}$ & $* * *$ & $\begin{array}{c}0.906 \\
(0.014)\end{array}$ & $* * *$ & $\begin{array}{c}0.915 \\
(0.011)\end{array}$ & $* * *$ \\
\hline Positive SA & $\begin{array}{c}0.136 \\
(0.013)\end{array}$ & $* * *$ & $\begin{array}{l}-0.052 \\
(0.024)\end{array}$ & $* *$ & $\begin{array}{l}-0.065 \\
(0.026)\end{array}$ & $* *$ & $\begin{array}{l}-0.060 \\
(0.016)\end{array}$ & $* * *$ \\
\hline Transfers major source & $\begin{array}{c}0.158 \\
(0.013)\end{array}$ & $* * *$ & $\begin{array}{c}-0.092 \\
(0.022)\end{array}$ & $* * *$ & $\begin{array}{l}-0.106 \\
(0.021)\end{array}$ & $* * *$ & $\begin{array}{l}-0.113 \\
(0.018)\end{array}$ & $* * *$ \\
\hline Positive earnings & $\begin{array}{c}-0.081 \\
(0.013)\end{array}$ & $* * *$ & $\begin{array}{c}0.007 \\
(0.023)\end{array}$ & & $\begin{array}{c}0.030 \\
(0.025)\end{array}$ & & $\begin{array}{c}0.039 \\
(0.020)\end{array}$ & $*$ \\
\hline Earnings major source & $\begin{array}{l}-0.193 \\
(0.014)\end{array}$ & $* * *$ & $\begin{array}{c}0.073 \\
(0.020)\end{array}$ & $* * *$ & $\begin{array}{c}0.074 \\
(0.020)\end{array}$ & $* * *$ & $\begin{array}{c}0.079 \\
(0.016)\end{array}$ & $* * *$ \\
\hline Earnings & $\begin{array}{c}-10035.5 \\
(627.0)\end{array}$ & $* * *$ & $\begin{array}{l}1010.9 \\
(555.5)\end{array}$ & $*$ & $\begin{array}{c}-4.1 \\
(503.7)\end{array}$ & & $\begin{array}{c}570.0 \\
(529.3)\end{array}$ & \\
\hline Social assistance & $\begin{array}{l}1040.6 \\
(136.4)\end{array}$ & $* * *$ & $\begin{array}{l}-746.9 \\
(292.8)\end{array}$ & ** & $\begin{array}{l}-825.2 \\
(289.8)\end{array}$ & $* * *$ & $\begin{array}{l}-886.3 \\
(206.2)\end{array}$ & $* * *$ \\
\hline Total Income & $\begin{array}{c}-7610.4 \\
(571.0)\end{array}$ & $* * *$ & $\begin{array}{l}1087.1 \\
(419.7)\end{array}$ & $* *$ & $\begin{array}{l}-844.5 \\
(605.6)\end{array}$ & & $\begin{array}{l}-389.9 \\
(405.7)\end{array}$ & \\
\hline Weeks worked & $\begin{array}{l}-6.5 \\
(0.7)\end{array}$ & $* * *$ & $\begin{array}{c}1.3 \\
(1.0)\end{array}$ & & $\begin{array}{c}1.2 \\
(0.8)\end{array}$ & & $\begin{array}{c}1.2 \\
(0.9)\end{array}$ & \\
\hline Hours worked & $\begin{array}{l}-290.7 \\
(27.8)\end{array}$ & $* * *$ & $\begin{array}{c}97.7 \\
(34.6)\end{array}$ & $* * *$ & $\begin{array}{c}70.4 \\
(26.0)\end{array}$ & $* * *$ & $\begin{array}{c}86.2 \\
(33.8)\end{array}$ & $* *$ \\
\hline
\end{tabular}

Notes: Reported is the coefficient on INTEBENS scaled in thousands of 2000 Canadian dollars. One, two, and three asterisks indicate statistical significance at the 10, 5, and 1 percent levels respectively. All specifications include dummies foryear, province, number of children, age of woman, education level, and presence of a child under age 6 . In the third column there are second-order interactions betweeen province, year, and presence of children dummies. In the fourth column there are secondorder interactions between province, year, and number of children dummies. 
Table 5: Sensitivity Regression Results

\begin{tabular}{|c|c|c|c|c|c|c|c|c|}
\hline & $(1)$ & & (2) & & (3) & & (4) & \\
\hline & $\begin{array}{c}\text { Base } \\
\text { results }\end{array}$ & & $\begin{array}{c}\text { mothers } \\
\text { of children } \\
\text { under } 6 \\
\end{array}$ & & $\begin{array}{c}\text { Just } \\
\text { women over } \\
\text { age } 24 \\
\end{array}$ & & $\begin{array}{l}\text { Exclude } \\
\text { Quebec }\end{array}$ & \\
\hline observations & 34018 & & 31314 & & 19280 & & 27553 & \\
\hline First stage & $\begin{array}{c}0.915 \\
(0.011)\end{array}$ & $* * *$ & $\begin{array}{c}0.853 \\
(0.011)\end{array}$ & $* * *$ & $\begin{array}{c}0.895 \\
(0.016)\end{array}$ & $* * *$ & $\begin{array}{c}0.882 \\
(0.017)\end{array}$ & $* * *$ \\
\hline Positive social assistance & $\begin{array}{c}-0.060 \\
(0.016)\end{array}$ & $* * *$ & $\begin{array}{l}-0.130 \\
(0.029)\end{array}$ & $* * *$ & $\begin{array}{l}-0.062 \\
(0.016)\end{array}$ & $* * *$ & $\begin{array}{l}-0.101 \\
(0.023)\end{array}$ & $* * *$ \\
\hline Transfers major source & $\begin{array}{c}-0.113 \\
(0.018)\end{array}$ & $* * *$ & $\begin{array}{l}-0.150 \\
(0.038)\end{array}$ & $* * *$ & $\begin{array}{l}-0.131 \\
(0.022)\end{array}$ & $* * *$ & $\begin{array}{l}-0.111 \\
(0.032)\end{array}$ & $* * *$ \\
\hline Positive earnings & $\begin{array}{c}0.039 \\
(0.020)\end{array}$ & $*$ & $\begin{array}{c}0.080 \\
(0.036)\end{array}$ & $* *$ & $\begin{array}{c}0.054 \\
(0.020)\end{array}$ & $* * *$ & $\begin{array}{c}0.027 \\
(0.022)\end{array}$ & \\
\hline Earnings major source & $\begin{array}{c}0.079 \\
(0.016) \\
\end{array}$ & $* * *$ & $\begin{array}{c}0.112 \\
(0.040)\end{array}$ & $* * *$ & $\begin{array}{c}0.093 \\
(0.020) \\
\end{array}$ & $* * *$ & $\begin{array}{c}0.078 \\
(0.030) \\
\end{array}$ & $* * *$ \\
\hline
\end{tabular}

Notes: Reported is the coefficient on INTEBENS reported in thousands of 2000 Canadian dollars. One, two, and three asterisks indicate statistical significance at the 10, 5, and 1 percent level respectively. All specifications include dummies foryear, province, number of children, age of woman, education level,and presence of a child under age 6. There are second-order interactions betweeen province, year, and family size dummies. 
Table 6: Regressions Including Other Benefits

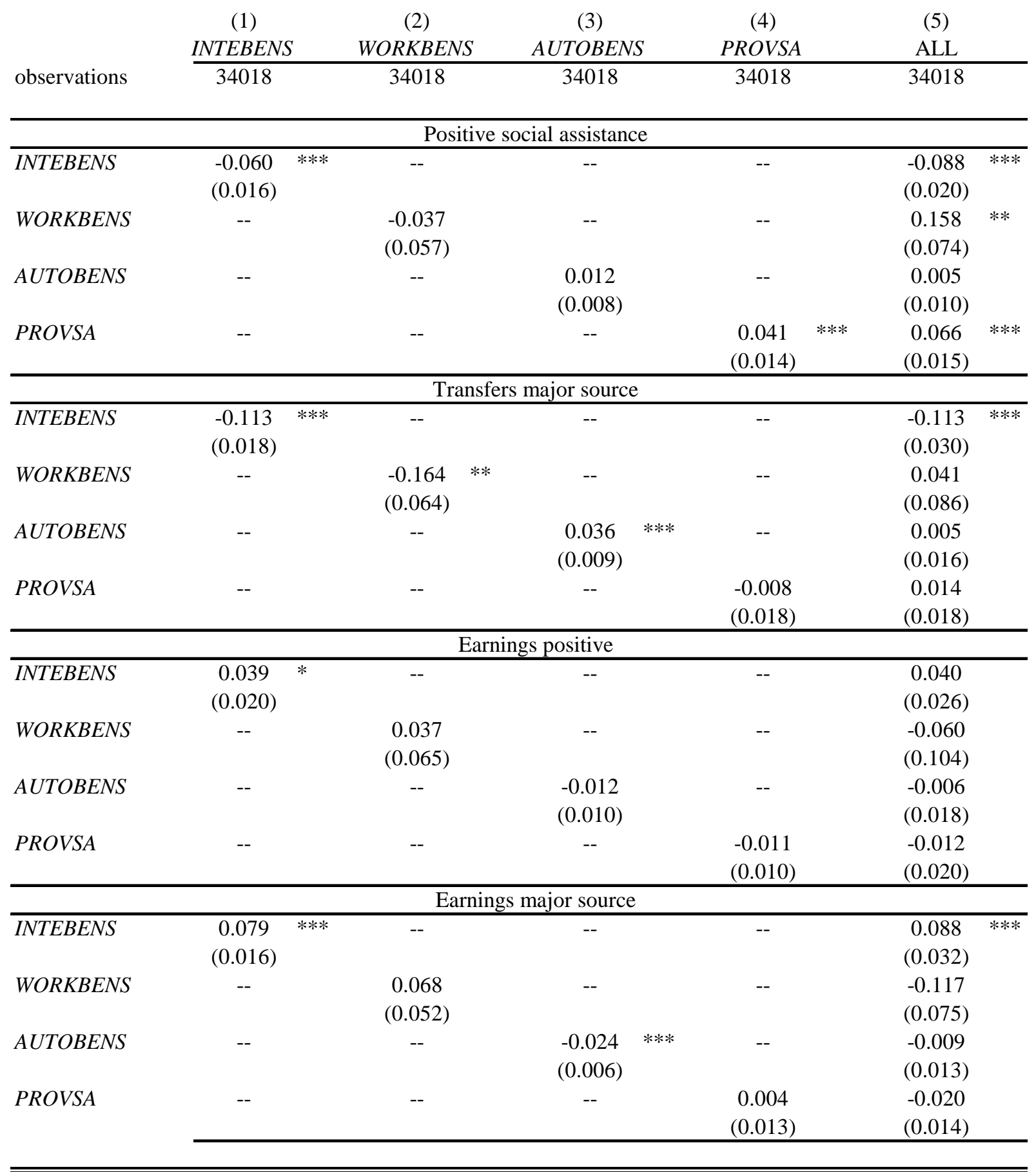

Notes: Reported are the coefficients on the noted policy variables, scaled in thousands of 2000 Canadian dollars. One, two and three asterisks indicate statistical significance at the 10, 5, and 1 percent levels, respectively. The control variables are the same as in Table 4, column 4. INTEBENS, WORKBENS, and AUTOBENS are instrumented using the corresponding policy instrument. 